\title{
Extrañamiento y desencanto. La mirada de documentalistas alemanes sobre la transición democrática argentina
}

\author{
Estrangement and disenchantment.The perspective of German \\ documentary filmmakers on Argentina's democratic transition

\section{Estranhamento e desencanto. O olhar de documentaristas alemães sobre a transição democrática argentina}

\author{
Paola Margulis'
}

Palabras clave:
Cine
Documental
Argentina
Dictadura
Transición democrática
El presente artículo analiza la mirada de dos cineastas alemanes sobre el proceso de transición democrática en Argentina a través del análisis de dos documentales: Del'Argentine / De la Argentina (Werner Schroeter, 1983-1985) y Kreuzzuggegen die Subversion / Panteón militar (Wolfgang Landgraeber, 1991). Estos films denuncian distintos aspectos del pasado traumático argentino, deteniéndose en las dificultades que encontraba hacia la década del ochenta y comienzos de la del noventa el Estado argentino para condenar los crímenes de lesa humanidad cometidos durante la última dictadura militar. El abordaje de estos documentales tendrá como objeto principal el estudio del tratamiento fílmico del "desencanto" que fue profundizándose en amplios sectores de la sociedad a partir de las leyes de prescripción de causas militares. 


\begin{abstract}
:
The present article examines the perspective of two German filmmakers on the process of democratic transition in Argentina through an analysis of two documentaries: De l'Argentine / De la Argentina/ For example Argentina (Werner Schroeter, 1983-1985) and Kreuzzuggegen die Subversion / Panteónmilitar (Wolfgang Landgraeber, 1991). These films denounce different aspects of Argentina's traumatic past, focusing on the difficulties that, during the 1980s and beginning of the 1990s, the Argentinean State was encountering to condemn crimes against humanity committed during the last military dictatorship. The approach to these documentaries will have as its main objective a study of the cinematographic take on the "disenchantment" that deepened among wide sectors of the society after the statutes of limitation on military trials.
\end{abstract}

\section{Keywords:}

Cinema

Documentary

Argentina

Dictatorship

Transition to democracy

\section{Palavras chave:}

\section{Cinema}

Documentário

Argentina

Ditadura

Transição democrática

\section{Resumo:}

O presente artigo analisa o olhar de dois cineastas alemães sobre o processo de transição democrática na Argentina através da análise de dois documentários: De l'Argentine / De La Argentina [Da Argentina] (Werner Schroeter, 1983-1985) e Kreuzzuggegen die Subversion/ Panteón militar [Panteão militar] (Wolfgang Landgraeber, 1991). Estes filmes denunciam distintos aspectos do passado traumático argentino,marcando as dificuldades que o Estado ia encontrando ao chegar na década de oitenta e no começo dos anos noventa para condenar os crimes de lesa humanidade cometidos durante a última ditadura militar. A abordagem destes documentários terá como objeto principal o estudo do tratamento fílmico do "desencanto" que foi se aprofundando em amplos setores da sociedade a partir das leis de prescrição de causas militares. 


\section{Extrañamiento y desencanto. La mirada de documentalistas alemanes sobre la transición democrática argentina}

La denuncia y la revisión del pasado dictatorial argentino (1976-1983) son algunas de las marcas centrales del cine documental político de la transición democrática realizado por cineastas exiliados o que residían en el exterior de su país durante aquellos años, desde perspectivas que recuperan las narrativas humanitarias (MARKARIAN, 2004; CRENZEL, 2008; CAMPO, 2017). Estas obras tienen el mérito de ser las primeras voces cinematográficas en denunciar el terrorismo de Estado, informar sobre los desaparecidos, brindar testimonio sobre la violencia y la tortura, y ubicar como un actor central -silenciado por aquel entonces en otros medios hegemónicos- a las Madres de Plaza de Mayo. Financiados generalmente por instituciones extranjeras -canales de TV, escuelas de cine, ONG- estos films tuvieron una circulación sumamente restringida en Argentina, hasta ser rastreados y recuperados como parte del acervo cultural nacional varias décadas más tarde. Si el conocimiento y circulación de estos films de por sí resultó marginal y escalonada, muchos menos conocida resulta la producción de cineastas extranjeros sobre la dictadura argentina. En general, estas películas permanecieron dispersas por el mundo, extraviadas, o simplemente desconocidas para el público sudamericano, en un tiempo en que los formatos de filmación y conservación no facilitaban el intercambio de materiales audiovisuales a nivel global.

En pocos años, instituciones alemanas produjeron o co-produjeron varios films documentales y ficcionales de directores argentinos y extranjeros que abordan, directa o indirectamente, el tema de la última dicta- dura argentina, entre ellos: Blauäugig / Ojos azules (Reinhard Hauff, 1989), Die Freundin / La amiga (Jeanine Meerapfel, 1988), Exilund Rükkerhr / Cuarentena. Exilio y regreso (Carlos Echeverría, 1984), Angelelli, con un oído en el pueblo y otro en el evangelio (Mario Bomheker, 1986), Juan, Alswärerichtsgeschehen / Juan, como si nada hubiera sucedido (Carlos Echeverría, 1987), Es gibtkein Vergessen/ Desembarcos (un taller de cine en Buenos Aires) (Jeanine Meerapfel, 1989), y Kreuzzuggegen die Suversion / Panteón militar (Wolfgang Landgraeber, 1991). Los vínculos entre Argentina y Alemania, junto con el paralelo que es posible trazar entre la Alemania nazi y la Argentina bajo el régimen militar, son probablemente los elementos que justifican el interés por parte de instituciones alemanas -principalmente canales de televisión- en producir películas que abordan la historia reciente del país sudamericano; como sugirieron algunos cineastas argentinos que asistieron al encuentro "Medios del Norte. Imágenes del Sur. Primer encuentro argentino-alemán sobre producción, distribución, y coproducción y fomento del cine documental" realizado en el Goethe Institut Buenos Aires en 1989 (MASSUH; GUARINI, 1990). Dichos aspectos fueron señalados como parte de un planteo destinado a destacar el modo en que el financiamiento europeo condiciona la mirada que impera en los films producidos desde el norte, orientando el tratamiento de estos temas hacia el espectador europeo". El film del realizador alemán Werner Schroeter, De l'Argentine/ De la Argentina (1983-85) financiado mayormente con capitales franceses, se sale de la circunscripción estrictamente alemana; sin embargo, la nacionalidad e identidad de su realizador permea su visión de mundo, manteniéndose de todos modos la hegemonía del eje de la mirada norte-sur.

Dentro de dicha serie, el presente artículo se concentrará en los dos documentales realizados por cineastas extranjeros que abordan aspectos traumáticos del pasado reciente argentino: De l'Argentine / De 
la Argentina (Werner Schroeter, 1983-1985) y Kreuzzuggegen die Subversion / Panteón militar (Wolfgang Landgraeber, 1991). Se trata en el primer caso de un film recientemente encontrado que ha tenido una circulación sumamente restringida en América Latina, y en el segundo, de un documental prácticamente desconocido para el público argentino. El abordaje de estos films tendrá como objeto principal el estudio del tratamiento fílmico del "desencanto", propio de la crisis de expectativas que fue tomando forma años después del retorno democrático. La noción de "desencanto" remite a un concepto "ubicuo, disputado, concreto para unos e inexistente para otros", una caracterización cuyo éxito pareciera residir, precisamente, en la dificultad para anclarlo y en la falta de referente preciso (EGEA, 2004, p. 81). Su asociación al proceso de transición democrática, viene dado por el precedente que marcó en España el documental de Jaime Chávarri, El desencanto (1976), el cual sirvió para titular y caracterizar a posteriori dicho período cultural (Egea, 2004, p. 81). En el caso argentino, la crisis de expectativas se puso de manifiesto por la dificultad para dar cumplimiento a la "promesa democrática", planteada como uno de los ejes principales de la campaña del luego electo presidente Raúl Alfonsín, ligada a “...la potencia de la justicia sobre los crímenes de lesa humanidad y el terrorismo de Estado" (CANELO, 2006, p. 86). Desde ese lugar, sostiene Alfredo Pucciarelli, "...la promesa incumplida se traduce en desilusión y desencanto frente a una democracia incapaz de resolver los grandes problemas que ella misma ha enunciado..." (PUCCIARELLI, 2006 , p. 146). Algunos hechos puntuales contribuyeron a generar dicha atmósfera social, como las cuatro rebeliones militares que tuvieron lugar durante la segunda parte de la década del ochenta, y ligadas a ellas, la promulgación de las Leyes de Punto Final"' (1986) y Obediencia Debidalv (1987), que colocaron límites a los juicios a distintos miembros de las fuerzas armadas durante el gobierno de Raúl Alfonsín. Estas leyes son incorporadas en un momento en el que el compromiso era alto, porque el juicio a las juntas militares en 1985 había constituido un proceso judicial sobre el que no había precedentes, sosteniendo las esperanzas de que la institución democrática pudiese dar curso a las reivindicaciones de verdad y justicia sostenidas por los organismos de derechos humanos. Con posterioridad, los indultos decretados entre 1989 y 1990 durante la administración de Carlos Saúl Menem, contribuyeron a clausurar dicho sistema de expectativas y a generar un sentimiento epocal de decepción en grandes sectores de la sociedad. Sin embargo, tal como señalan Carlos Acuña y Catalina Smulovitz, a pesar de las limitaciones de los alcances de la política de sanciones, el indulto y la liberación de los condenados, la distribución de costos y beneficios políticos que resultó de los juicios no pudo ser totalmente revertida: "Una vez que la lógica jurídica transformó a los datos de la historia en pruebas, ni el indulto ni la amnistía pudieron retrotraer la cuestión de los derechos humanos a situaciones en las que una ley de olvido o una amnistía anticipada evitan toda investigación y juzgamiento" (ACUÑA; SMULOVITZ, 1995, p. 22). En esas circunstancias, aquellos que se beneficiaron con estas leyes, debieron admitir que los hechos por los cuales se los eximía de castigo, eran delitos (ACUÑA; SMULOVITZ, 1995$, p. 65$)^{v}$.

En el marco de este trabajo, argumentaremos que junto con la desilusión por las leyes de prescripción de causas -también conocidas como leyes del olvido- $y$ en general las políticas regresivas en materia de derechos humanos, el desencanto también está dado por la dimensión económica, a partir de miradas críticas sobre un modelo de sociedad en el que se acentúan las desigualdades sociales. Con ese objetivo en miras, nos concentramos en el modo en que De la Argentina y Panteón militar retratan la sociedad argentina, $y$ en especial, el seguimiento de la problemática de los derechos humanos y las 
leyes de prescripción de causas militares. Más allá de las diferencias que establece el eje temporal en el tratamiento de este tema, se destaca en estos dos documentales la exaltación de los opuestos a través de la comparación en general y del montaje alternado en particular, el cual "....abre la puerta a todos los 'simbolismos'” (METZ, 1974, p. 149). En estosfilms, la exaltación de opuestos tiende a enfatizar las tensiones y conflictos irresueltos durante la transición, y las dificultades en la instancia de "consolidación democrática". vi

\section{El desencanto anunciado: De la Argentina}

Antes, incluso, de la promulgación de las leyes de prescripción de causas militares hacia mediados de la década del ochenta, algunos documentales ya señalan en tiempo presente los conflictos que desencadenarán el desencanto de posteriores años. Tal es el caso del film De la Argentina ${ }^{\text {VII }}$ (1983-1985) del realizador alemán Werner Schroeter. Se trata de una película poco habitual en el contexto de la postdictadura argentina, que se exhibió en dicho país recién en 2013, cuando su copia fue encontrada en la Cinemateca francesa. VIII De la Argentina observa el contexto argentino postdictadura a partir de la mirada extrañada y foránea de su realizador, caracterizada por un estilo irreverente y provocador que incluye escenificaciones, e irónicas apariciones del mismo Schroeter frente a cámara. Este film-ensayo de carácter documental aborda los horrores vividos durante el terrorismo de Estado contrastando las declaraciones oficiales del régimen con el testimonio de miembros de organismos de derechos humanos, víctimas y familiares de desaparecidos. A su vez, la película también promueve una agenda propia que incluye temas de género, libertades sexuales, y crítica a la sociedad patriarcal. Estos ejes - que evidentemente constituyen intereses e inquietudes personales de Schroeter - posiblemente resultaran habituales en el contexto de la Ale- mania de la década del ochenta, pero eran mucho menos frecuentes en el documental argentino postdictadura.

Uno de los puntos nodales del film De la Argentina, apunta precisamente a las dificultades que hacia mediados de la década del ochenta encontraba el gobierno de Raúl Alfonsín para dar curso a los juicios por los crímenes de lesa humanidad cometidos durante la última dictadura militar. En uno de los tramos más significativos a este respecto, mediante la contraposición de discursos antagónicos, se contrasta la posición asumida por el gobierno de Raúl Alfonsín y los argumentos sostenidos por distintos miembros de organismos de derechos humanos respecto de cómo operativizar las acciones de justicia, para darle curso legal a las condenas de los militares. Más allá de esta primera contrastación, el documental no pasa por alto las diferencias que sobre este tema sostienen integrantes de diferentes organismos de derechos humanos, deteniéndose especialmente en las disidencias entre Madres y Abuelas de Plaza de Mayo en torno de la creación de la Comisión Nacional sobre la Desaparición de Personas (CONADEP). IX

En un contexto en el que desde el poder se alentaba a minimizar el conflicto con el objeto de "no desestabilizar" al nuevo gobierno, la mirada foránea de Schroeter exalta precisamente estas problemáticas que pretendían ser aminoradas. Así, mediante el montaje alternado, el film contrapone los discursos públicos de Raúl Alfonsín durante la marcha "en apoyo de la democracia" por él mismo convocada para el 26 de abril de 1986; y la palabra de Hebe de Bonafini, la cual se solapa con imágenes de distintas intervenciones de Madres de Plaza de Mayo, destacándose entre ellas, la "marcha de las manos" realizada en 1985. Para dicho evento el espacio aéreo de Avenida y Plaza de Mayo fue cubierto por un millón de contornos de manos firmadas en su interior por distintas personalidades na- 
cionales e internacionales, avalando la consigna "No a la amnistía. Juicio y castigo a los culpables". Por momentos, el audio de ambos discursos se superpone, e incluso, la voz de Bonafini es articulada con las imágenes de las masas convocadas por el presidente. Mientras que la figura de Alfonsín está fuertemente presente en pantalla, fundiéndose incluso con los muchos que le brindan apoyo, la imagen de Bonafini no es mostrada visualmente. Su corporalidad se hace presente únicamente a partir del registro sonoro de su voz, el cual cobra mayor intensidad durante la lectura del poema de Pablo Neruda Los Enemigos, que dio cierre a su intervención. De ese modo, el montaje alternado contrapone los argumentos de Alfonsín, tendientes a relativizar la responsabilidad de las Fuerzas Armadas en el ejercicio del terrorismo de Estado, junto con la fuerza emocional de la voz de Bonafini al reiterar la frase "pido castigo", que funciona como leitmotiv del poema de Neruda.

En el contexto de un gobierno que tocaba "...los límites que le opusieron la agudización de la crisis económica y las movilizaciones corporativas de las principales organizaciones del capital y del trabajo" (NUN, 1987, p. 48), los discursos de Alfonsín que aparecen en el film de Schroeter, no son ya los que promovían la promesa de la democracia (la célebre fase "con la democracia se come, con la democracia se educa, con la democracia se cura" pronunciada en su discurso inaugural); sino aquellos otros que - anticipando el desencanto de posteriores años - darían cuenta de la fragilidad de la conquista democrática, la necesidad de defenderla, y las presiones de distintos sectores, principalmente del ejército, para evitar llevar adelante los juicios. Según explica Roberto Gargarella (2010, pp. 35-36) el discurso de Alfonsín habría generado una fuerte desilusión en los asistentes a la marcha:

aquejado por una grave crisis económi$\mathrm{ca}$, y enfrentando los primeros rumores de inestabilidad... (...) La expectativa era que Alfonsín hablara del golpe en ciernes; sin embargo, frente a la multitud, el Presidente no se refirió a la amenaza del golpe, sino que hizo referencia a la llegada de una "economía de guerra" (la necesidad de una política de riguroso ajuste económico), invocación frente a la cual la ciudadanía — de fortísimas simpatías alfonsinistas- no pudo sentir sino decepción. ${ }^{X}$

\section{Gabriel}

El factor económico del desencanto es constantemente señalado en el film de Schroeter por medio del testimonio de distintos entrevistados, pero también, y fundamentalmente, por la presencia destacada de un niño de sectores humildes llamado Gabriel. Su pertenencia de clase y su rol social no son explicitados por el film en forma contextual, puesto que nunca se muestra a sus padres o se alude al marco situacional en el que vive y se desenvuelve normalmente. Por el contrario, Gabriel aparece arrancado de su cotidianeidad y de sus lazos sociales, interactuando con adultos en espacios y situaciones artificiales en los que se destaca el control sobre la puesta en escena. Por momentos, el niño entra en diálogo con Schroeter o con algún miembro del equipo de filmación, mientras que en otros, forma parte de acciones abiertamente planificadas o coreografiadas en las que interactúa con actores o cantores.

El lugar alegórico que ocupa Gabriel en el film está dado precisamente por su corta edad y su extracción social. Se trata de un niño que no conoció otra Argentina que la de la dictadura -a partir de una posición socio-económica marginal-, y que atraviesa un presente en el que a sus ojos, el porvenir se muestra desencantado, sin sueños ni esperanzas a futuro. Ante las preguntas que le dirigen sus entrevistadores, inquiriendo qué entiende por 
conceptos complejos como "libertad", "democracia", etc., Gabriel va rotando sus respuestas (puesto que las preguntas muchas veces se reiteran), sosteniendo que dichos conceptos no son "nada", o por ejemplo, que "la libertad, [significa] que estamos libres, podemos ir a robá (sic)". Más allá del agudo control sobre la puesta en escena -y posiblemente sobre algunos diálogos-, la mirada resignada y desesperanzada de quien estuvo siempre fuera del sistema, señala continuidades entre el régimen militar y el civil que no se extinguen con el retorno democrático, y que por eso mismo, difícilmente puedan idealizar a este último.

A este respecto, uno de los momentos más llamativos del film, involucra la figura de Gabriel junto con la de la emblemática actriz Libertad Leblanc, ícono sexual de las décadas del sesenta y setenta, quien personifica a Eva Perón, la "abanderada de los humildes", luciendo lujosos vestidos que alguna vez pertenecieron a la esposa de Juan Domingo Perón. Más allá de los obvios contrastes entre las imágenes de Eva y Leblanc luciendo el mismo atuendo, estos pasajes también destacan con ironía las contradicciones entre la ostentación y las políticas sociales que le dieron identidad al peronismo. Así, mientras la cámara se detiene en las réplicas de las joyas de Eva, la voz superpuesta de Enrique Pinti -correspondiente a uno de sus monólogos en Salsa Criolla-, alude a las vacaciones pagas, al aguinaldo, la compra de electrodomésticos, y otras reivindicaciones que los trabajadores obtuvieron durante el primer peronismo. Con posterioridad, Gabriel, arrodillado a los pies de la sensual Leblanc le pregunta: "Evita, ¿cómo te sentís ahora que no estás con nosotros?". A diferencia de otras personificaciones de Eva que aparecen en el documental, la de Libertad Leblanc interactuando con Gabriel parecería constituir un simulacro, en el mismo sentido en que lo postula el cuento de Jorge Luis Borges (1974, p. 789) que lleva el mismo nombre. En el cuento, el simulacro del velatorio de Eva -representada por una muñeca rubia en un cajón junto a un hombre que personifica al General- es completado por la congregación de seguidores que se acercan a darle el pésame a Perón y despedirse de los restos de su esposa. Por su parte, en el film de Schroeter, la escena simulada se completa con Gabriel, niño de orígenes humildes que bien podría ser destinatario de las políticas encaradas por la fundación Eva Perón. Al igual que en la ficción de Borges, la simulación de Schroeter se completa con la realidad corporal del pueblo seguidor de Eva y la pasión manifestada hacia sus líderes. Por otra parte, al incorporar estos pasajes en los que se conjugan la ostentación y la fuerte vinculación con los sectores populares, Schroeter dirige una aguda mirada sobre algunas de las contradicciones que caracterizaron al primer peronismo, en un momento histórico de crisis, luego de la primera derrota de este movimiento político en elecciones democráticas. En dichas circunstancias, la representación de los sectores carenciados - identificados históricamente con los íconos del peronismo- constituye un área en disputa.

\section{El desencanto como clima de época: Panteón militar}

Si en términos generales en el documental de los ochenta el desencanto aparece principalmente ligado a la promulgación de la Ley de Punto Final; traspasando el umbral de la década del noventa -luego de las rebeliones militares y de los indultosla desilusión se convertirá en un clima epocal de desesperanza generalizada, fuertemente ligado al giro neoliberal y a la pátina de corrupción e impunidad atribuidas al menemismo. En dicho contexto, Panteón militar (Wolfgang Landgraeber, 1991) propone un escenario fuertemente polarizado en el que se destacan la impunidad y las contradicciones entre ideas, clases y sectores sociales. El film de Landgraeber analiza la matriz ideológica que caracteriza a la institución militar argentina, sus referentes, 
y algunas consecuencias de su accionar luego de la última dictadura militar. El documental va siguiendo las vinculaciones entre los ejércitos alemán y argentino, a partir de la posición de referencia que establece el cuerpo militar europeo sobre el sudamericano, pero también, y fundamentalmente, a partir de su rol como proveedor de armamento a la Argentina desde principios del siglo XX, deteniéndose específicamente en el período de la última dictadura militar (1976-1983). De ese modo, la mirada sobre el terrorismo de Estado está mediada, ya desde el comienzo, por la dimensión económica. En el inicio del film unos intertítulos en alemán -leídos en español por una voz over- organizan un prólogo contextual en el que se articula el accionar coercitivo de las fuerzas armadas durante la dictadura -por medio de la práctica de desaparición de personas-, junto con la compra de armas a Alemania como uno de los desencadenantes del incremento de la deuda externa argentina, destacando también las cuatro rebeliones militares que precipitarían luego la amnistía. A su vez, a lo largo de su desarrollo, el film aborda algunas de las consecuencias de la política neoliberal del gobierno menemista, en particular, el impacto del compromiso de pago de la abultada deuda externa sobre algunos de los sectores más vulnerables de la sociedad argentina, como los jubilados y grupos de bajos recursos económicos.

En el film, la figura de Osvaldo Bayer -intelectual de ascendencia alemana que debió exiliarse en Berlín durante los años de represión- actúa como nexo entre ambos países, compartiendo a través de un intercambio epistolar ficcionalizado dirigido a un amigo, distintos parámetros de la situación contextual, junto con aspectos de su historia y experiencia personales durante la dictadura y transición democrática. La perspectiva de Bayer es también complementada con entrevistas a militares y ex militares defensores y detractores del rol y los valores de las Fuerzas Armadas argentinas, en especial en lo que respecta a su papel durante la última dictadura. La vinculación de Bayer con esta historia se da a partir de la publicación de una de sus obras más destacadas, La Patagonia rebelde ${ }^{\mathrm{XI}}$-libro que inspiró un film con el mismo nombre dirigido por Héctor Olivera (1974), en el cual el historiador participó como guionista-, y también por sus investigaciones sobre el militarismo y la influencia de lo prusiano en los militares argentinos.

La labor de Wolfgang Landgraeber como documentalista y productor, ha estado vinculada con el periodismo de investigación en la televisión pública alemana (WDR), y ha mostrado a lo largo de su carrera, un sostenido interés por temas vinculados con el militarismo y la exportación de armas. En el caso de Panteón miliar, la mirada foránea de Landgraeber se traslada principalmente a la ironía y el extrañamiento - aspectos que también comparte con De la Argentina. La ironía se advierte, principalmente, en la editorialización a través del uso de la banda sonora, rompiendo el clima ceremonial de protocolos de distintos eventos, ridiculizando desfiles militares, e incluyendo, incluso, un inusual versionado del himno nacional argentino hacia el final del film, mientras se exhibe en pantalla la imagen del panteón militar. La mirada extranjera se percibe también en el afán irónico por ubicar reiteradamente en lugar de centralidad la admiración que sienten ciertos militares argentinos por los valores del ejército prusiano -considerados en muchos casos anacrónicos por los propios alemanes-, y su orgullo por la utilización de armamento del país nórdico. Pero independientemente de la mirada externa de Landgraeber, el film también incluye la participación de un realizador argentino, Carlos Echeverría, quien decidió no participar de la edición final ni figurar en los créditos como co-autor, debido a desavenencias con el director alemán. Más allá de esta decisión final, Echeverría habría dedicado alrededor de ocho años de investigación a la preproducción de Panteón militar, film cuya temáti- 
ca se encuentra muy cercana a algunos de sus trabajos previos realizados en Alemania y Argentina para cine y televisión. ${ }^{\mathrm{XII}}$

Alejado temporalmente de la mayor parte del cine documental humanitario "del retorno" propio de la década del ochenta, Panteón militar surge cuando los indultos ya habían clausurado por completo toda esperanza de justicia transicional. En dicho contexto, el documental alude a la amnistía como hecho consumado, a través de las percepciones que Osvaldo Bayer le transmite a un amigo, en un intercambio epistolar ficcionalizado:

Si bien los verdugos uniformados fueron castigados por la justicia por sus crímenes, los políticos oportunistas proclamaron muy pronto su amnistía. Hoy se puede ver a los asesinos caminar tranquilos por las mismas calles donde secuestraron a sus víctimas.

En un sentido similar, el historiador también cuestiona la base ética que sostiene las Ley de Obediencia Debida:

Todos los oficiales, desde Subteniente a General, sabían muy bien los métodos que se aplicaban, pero todos, absolutamente todos, se ampararon en la Obediencia Debida. Ni un solo oficial argentino para demostrar su inocencia y defender su honor rechazó la clemencia oficial y exigió que se le hiciera un juicio para demostrar su inocencia. ¿Dónde quedó el honor de los últimos prusianos, como gustan en llamarse los militares argentinos?

\section{La comparación}

Al igual que en De la Argentina parte de la mirada crítica aparece en el film de Landgraeber a partir de la exaltación de opuestos. En Panteón militar, los opuestos son construidos y destacados en forma es- quemática por la comparación, la cual es en algunos casos vehiculizada por la reflexión de Bayer, mientras que en otros es generada por medio del montaje alternado. Una de estas comparaciones, explica precisamente el título del film. En ella, la voz de Osvaldo Bayer contrapone un monumento situado en el cementerio de Generales prusianos, cerca del aeropuerto berlinés de Tempelhof, y el Panteón militar argentino. El primero, señala el historiador, ha quedado arrinconado, "un cementerio olvidado y molesto", un sitio anacrónico que

no es solo una población de muertos, sino también un lugar sin vida. Pareciera ser un gigantesco monumento a la obediencia y la agresión, las dos características fundamentales de la vida de un militar. En mi país, Argentina, se cree todavía en todo eso, como si nos hubiéramos detenido efectivamente en el tiempo.

Las imágenes de una clase de instrucción en el Colegio Militar argentino, articuladas con la reflexión de Bayer, permiten constatar cómo los cuadros militares argentinos son formados tomando como referente imágenes del ejército prusiano proyectadas en un televisor, precisamente aquella fuerza que el intelectual descalifica como decadente dentro del propio imaginario alemán. Como parte de este patrón cultural argentino extemporáneo, Bayer nota:

En Argentina, los oficiales muertos son depositados en el Panteón Militar, al compás de bronces, tambores y discursos. Se les dedica monumentos de cuerpo entero sobre los que no se posa ningún pájaro. Se creen inmortales y mueren ya antes de morir.

Las imágenes que acompañan esta reflexión presentan a Bayer en el cementerio de los militares prusianos de Berlín, contemplando un monumento de gran magnitud. Dicha perspectiva se compone por planos 
amplios, que buscan abarcar la inmensidad de la estatua, recorriendo verticalmente los rasgos de un militar que se encuentra de pie, junto a la figura de un ataúd que deja entrever, por debajo del capote que cubre el cuerpo, los puños cerrados del cadáver que asoman, como dando batalla desde la muerte. El detalle de los puños cerrados del monumento, conecta a través del montaje con un gesto similar que adoptan las manos de un joven que toma clases en la institución militar argentina. Las palabras de Bayer, aludiendo a la decadencia de lo prusiano, permiten en el caso argentino invertir el concepto: si el monumento muestra a un militar alemán que sigue dando batalla aún desde la muerte; la imagen del puño cerrado del estudiante argentino muestra la reproducción viva del ejército argentino a partir de doctrinas que ya han fenecido. El lugar de la mirada, emplazada desde la perspectiva de un realizador alemán y mediada por la ironía, resalta el lugar de subalternidad de la posición argentina, que sigue consumiendo con orgullo ciertos arquetipos en desuso, mientras Alemania sigue generando dividendos por el prestigio prusiano.

\section{El hambre y la comida}

Otro de los momentos que sintetizan el desencanto por el endeudamiento y las políticas económicas durante la década del noventa, remite a una contraposición que mediante el montaje alternado contrasta la situación de lujo de ciertos eventos protocolares militares, y la precariedad que atraviesan las personas de la tercera edad. Por medio de esta comparación podemos ver una olla popular organizada por jubilados como medida de lucha frente al empeoramiento de sus condiciones de vida. Los vemos en la calle, preparando la comida en grandes cacerolas, y luego sentados en bancos, para ingerir los alimentos. El montaje del film alterna estas vistas de los ancianos, con otras imágenes que exhiben eventos militares en los que se destacan las armas y la comida. Una de estas series - en la que nos concentraremos - muestra una sofisticada ceremonia protocolar en la embajada de Alemania, la cual tiene por objeto condecorar a dos militares argentinos que se han especializado en el uso de equipamiento militar alemán, gracias a la cooperación entre las fuerzas armadas de uno y otro país. La simbología de "el hambre y la comida" es construida, obviamente, al intercalar imágenes de los jubilados repartiéndose trozos de pan en la olla popular, con el metraje correspondiente al sofisticado cóctel en la embajada, en el que continuamente circulan elegantes bandejas para agasajar a los uniformados de alto rango. Luego, la cámara que hasta el momento no se había salido del protocolo de filmación institucional propia de dichos eventos sociales -atendiendo a los protagonistas del acto y paneando hacia los costados para registrar la presencia de los invitados- comienza a tomar un rol más incisivo a partir de la focalización en ciertos grupos de asistentes y el registro de sus conversaciones. El film se interesa en especial por un círculo de individuos, algunos militares y otros ciudadanos civiles, que mantienen una conversación mientras disfrutan del cóctel. La lente se detiene inicialmente en sus rostros - que se recortan irónicamente sobre el fondo de una bandera argentina colgada detrás de ellos- mientras uno de ellos se refiere a lo hermética que encuentran la situación en dicho momento, optando luego el montaje por sostener la continuidad sonora del diálogo - mientras este adquiere un matiz más comprometedor- para concentrarse en algunos detalles de las espaldas, insignias, y las manos de los asistentes. Esta operación tiende reforzar el protagonismo del plano sonoro, mientras uno de ellos afirma: "...no debe olvidarse que el Cordobazo empieza a través de un pequeño problema en un comedor universitario, ¿se acuerda? Así empezó el derrocamiento de... o sea la caída de un gobierno...". Este fragmento forma parte de un intercambio que no estaba destinado 
a hacerse público. Se trata de una conversación informal, posiblemente trivial en el universo de las personas que la sostienen, que al ser integrada a la mirada crítica y extrañada del film, genera cierta distancia en el espectador. Sus participantes se muestran conscientes de la presencia de la cámara, pero no parecen prestar mucha atención al resguardo de sus conversaciones, dado que como es habitual en este tipo de eventos, el audio suele descartarse por resultar irrelevante y/o por estar viciado por el sonido ambiente. Como es de esperarse, la planificación del film se sale de la formula de registro habitual en este tipo de acontecimientos y opta por conservar la banda de sonido ahogada por el bullicio, dejando de lado la imagen de los participantes que parecería estar tomada con nitidez-. Al igual que en otros momentos del film, estas acciones le permiten a Landgraeber ironizar sobre las características del protocolo militar y diplomático.

Si bien las palabras de este pequeño grupo de asistentes constituyen un lugar común en el patrón de pensamiento militar que ayuda a reconstruir el film -en el que fácilmente tienen lugar la legitimación de un régimen dictatorial y la desligitimación de un movimiento popular-, este fragmento, sin embargo, extracta la preocupación por la coyuntura política de la Argentina, y en especial, la intranquilidad que cualquier manifestación de disconformidad podría generar. Pero a diferencia de fines de la década del sesenta, cuando tuvo lugar el Cordobazo, en el presente del film no son los estudiantes los que están en las calles, sino los ancianos -como describe el montaje alternado- cuya vulnerabilidad pasa, entre otras cosas, por no constituir un grupo de presión frente a las políticas de ajuste que estaba poniendo en marcha el gobierno. De este modo, estas palabras se vuelven una cáscara discursiva hueca, un simple lugar común dentro del repertorio conservador, que pareciera decir más de quién lo dice que de la coyuntura argentina de dicho momento.

\section{A modo de conclusión}

Luego de este recorrido, notamos que la diferente inscripción temporal de Panteón militar y De la Argentina -el transcurrir de los años ochenta hasta comienzos de los noventa-, resulta un factor determinante en lo que refiere a la organización de ejes de conflictos y alusión al marco contextual. Si en De la Argentina los problemas de la transición remiten a grupos acotados y específicos de la sociedad -como los organismos de derechos humanos, el gobierno, el ejército-; en Panteón militar el desencanto aparece como un clima de época generalizado. Sin embargo, y más allá de las diferencias contextuales, tanto en uno como en otro film la desilusión alude tanto a las políticas regresivas en materia de derechos humanos, como a la política económica. En términos generales, las presiones que el gobierno de Raúl Alfonsín sufría por parte del ejército y otros sectores, no suelen aparecer problematizas en estos films, y cuando se insinúan algunas vetas de estos conflictos, son en general leídos como marcas de la continuidad entre dictadura y democracia, destacando la deuda pendiente que el nuevo gobierno debía saldar en materia de derechos humanos.

Si en el film de Schroeter el factor económico aparece más que nada en forma alegórica, en el de Landgraeber este eje asume formas concretas, a partir de la política de corte neoliberal que incluye el ajuste, la flexibilización laboral y el compromiso de pago de la deuda externa (contraída en gran parte durante la última dictadura militar). En ambos films tiene mucho peso la exaltación de opuestos y la comparación, vehiculizada a partir de los simbolismos que construye el montaje alternado, en los que se destaca el lugar de los sectores más vulnerables de la sociedad: los niños en un caso, los ancianos en el otro. 
Tanto uno como otro film observan las continuidades entre dictadura y democracia, pero lo hacen desde lugares contrapuestos: De la Argentina ubica el peso de su mirada en los organismos de derechos humanos, mientras que Panteón militar sigue de cerca la institución castrense. Ambas perspectivas, no obstante, resaltan las continuidades entre dictadura y democracia, la forma en que la primera sobrevive en la segunda y el modo en que la democracia lleva intrínseca el germen de la violencia militar. Estas circunstancias vuelven especialmente relevante la reflexión de Silvia Schwarzböck, quien al respecto sostiene que "... la postdictadura es lo que queda de la dictadura, de 1984 hasta hoy, después de su victoria disfrazada de derrota" (SCHWARZBÖCK, 2016, p. 23), XIII y por lo tanto, "[l]o que en democracia no se puede concebir de la dictadura, por más que se padezcan sus efectos, es aquello de ella que se vuelve representable como postdictadura: la victoria de su proyecto económico / la derrota sin guerra de las organizaciones revolucionarias / y la rehabilitación de la vida de derecha como la única vida posible" (SCHWARZBÖCK, 2016, p. 23; el resaltado corresponde al original). Las miradas distanciadas de estos cineastas alemanes, y su ironía, en definitiva, acaso estén haciendo visible la presencia de ese resto.

\section{Bibliografía}

ACUÑA, Carlos; SMULOVITZ, Catalina. Militares en la transición argentina: del gobierno a la subordinación constitucional. In: VVAA. Juicio, castigos y memorias. Derechos humanos y justicia en la política argentina. Buenos Aires: Nueva Visión, 1995. p. 21-99.

BORGES, Jorge Luis. El simulacro. In: Obras completas. Buenos Aires: Emecé, 1974. p. 789.

CAMPO, Javier. Revolución y democracia. El cine documental argentino del exilio (1976-1984). Buenos Aires: Ciccus, 2017.
CANELO, Paula. La descomposición del poder militar en la Argentina. Las Fuerzas Armadas durante las presidencias de Galtieri, Bignone y Alfonsín (1981-1987). In: PUCCIARELLI, Alfredo (coord.). Los años de Alfonsín: ¿El poder de la democracia o la democracia del poder? Buenos Aires: Siglo Veintiuno Editores, 2006. p. 65-114.

CRENZEL, Emilio. La historia política del Nunca Más: La memoria de las desapariciones en la Argentina. Buenos Aires: Siglo Veintiuno, 2008.

EGEA, Juan. El desencanto: La mirada del padre y las lecturas de la transición. Symposium: A QuarterlyJournal in Modern Literatures, vol. 58, Issue 2, 2004. p. 79-92.

GARGARELLA, Roberto. Democracia y derechos en los años de Raúl Alfonsín. In: GARGARELLA, Roberto; MURILLO, María Victoria; PECHENY, Mario (comps.). Discutir Alfonsín. Buenos Aires: Siglo Veintiuno, 2010. p. 23-40.

MARKARIAN, Vania. De la lógica revolucionaria a las razones humanitarias: la izquierda uruguaya en el exilio y las redes transnacionales de derechos humanos (1972-1976). Cuadernos del Claeh, ${ }^{\circ}$ 89, año 27, 2004. p. 85-108.

MASSUH, Gabriela; GUARINI, Carmen. Medios del Norte. Imágenes del sur. Primer encuentro argentino-alemán sobre producción, distribución, coproducción y fomento del cine documental. Buenos Aires: Goethe Institut Buenos Aires, 1990.

METZ, Christian. La gran sintagmática del film narrativo. In: VVAA. Análisis estructural del relato. Buenos Aires: Tiempo Contemporáneo, 1974. p. 147-153.

NUN, José. La teoría política y la transición democrática. In: NUN, José; PORTANTIERO, Juan Carlos (eds.). Ensayos sobre la transición democrática en la Argentina. Buenos Aires: Punto Sur, 1987. p. 15-56.

PORTANTIERO, Juan Carlos. La transición entre la confrontación y el acuerdo. In: NUN, José; PORTANTIERO, Juan Carlos (eds.). Ensayos sobre la transición democrática en la Argentina. Buenos Aires: Punto Sur, 1987. p. 257-293.

PUCCIARELLI, Alfredo. La República no tiene Ejército. El poder gubernamental y la movilización popular durante el levantamiento militar de Semana Santa. In: PUCCIARELLI, Alfredo (coord.). Los años de Alfonsín: ¿El poder de la democracia o la 
democracia del poder? Buenos Aires: Siglo Veintiuno Editores, 2006. p.115-151.

SCHWARZBÖCK, Silvia. Los espantos. Estética y postdictadura. Buenos Aires: Cuarenta Ríos, 2016.

\section{Recebido em 03/07/2018 Aprovado em 27/08/2018}

I Argentina. Paola Margulis. Doutora em Ciências Sociais pela Universidad de Buenos Aires. Conicet. Universidad de Buenos Aires, Instituto de Investigaciones Gino Germani, Faculdad de Ciencias Sociales. Contato: paomargulis@yahoo.com

II Al respecto, ver las intervenciones de Humberto Ríos y Carlos Echeverría en los debates que formaron parte del encuentro "Medios del Norte. Imágenes del Sur. Primer encuentro argentino-alemán sobre producción, distribución, coproducción y fomento del cine documental" (MASSUH; GUARINI, 1990).

III La Ley de Punto Final N²3.492 estableció la caducidad de la acción penal contra los imputados como autores de haber cometido el delito de desaparición forzada de personas durante la dictadura militar que no hubieran sido llamados a declarar antes de los sesenta días corridos a partir de la fecha de promulgación de dicha ley.

IV La Ley de Obediencia debida $\mathrm{N}^{\circ}$ 23.521estableció una presunción (que no admitía prueba en contrario) de que los delitos cometidos por los miembros de las Fuerzas Armadas (cuyo grado fuera menor al de coronel) durante el terrorismo de estado y la dictadura militar no eran punibles, por haber actuado en virtud de la "obediencia debida".

V En agosto de 2003, se promulgó la ley 25.779, que anula las leyes de Punto Final y de Obediencia Debida. Junto con ello, un fallo de la Corte Suprema de Justicia, que declara la invalidez e inconstitucionalidad de ambas leyes, habilitó el avance de las causas judiciales por los delitos cometidos durante la dictadura militar.

VI Entendemos la "consolidación democrática" como una de las instancias involucradas en el proceso de transición. Según la periodización que establece Juan Carlos Portantiero (1987, pp. 262-264), el proceso de transición democrática estaría compuesto por tres momentos: en primer lugar la "crisis del autoritarismo", seguida luego por un segundo momento de "instalación democrática", para dar lugar por último a la "consolidación" de dicho régimen. El éxito de ésta última etapa es alcanzable recién en el momento en que se logre una regulación estable de las formas de la democracia política y de la presencia de los intereses del Estado.

VII Agradezco al Goethe Institut de Buenos Aires el acceso al film.

VIII El documental fue exhibido como parte de una retrospectiva de Werner Schroeter titulada "Werner Schroeter. Superar la insoportable realidad", co-organizada por el Goethe Institut de Buenos Aires y la Fundación Cinemateca Argentina y tuvo lugar en la Sala Leopoldo Lugones del Complejo Teatral de Buenos Aires entre el 17 de agosto y el 1 de septiembre de 2013.

IX La asociación Madres de Plaza de Mayo ha sido uno de los organismos de derechos humanos que se mostró más crítico ante la creación de la Comisión Nacional sobre la Desaparición de Personas (CONADEP) —organismo destinado a recabar información sobre las personas desaparecidas durante la dictadura. Su rechazo a esa iniciativa se debió a su carácter extraparlamentario y por carecer de facultades coercitivas para obligar a los militares a declarar (Crenzel, 2008). Sobre este tema véase también Acuña y Smulovitz, 1995.

X Roberto Gargarella, "Democracia y derechos en los años de Raúl Alfonsín", en Discutir Alfonsín, Ed. Roberto Gargarella, María Victoria Murillo, y Mario Pecheny (Buenos Aires: Siglo Veintiuno, 2010), 35-36.

XI La Patagonia rebelde narra los hechos vinculados al fusilamiento de alrededor de 1500 peones luego de una huelga rural que tuvo lugar en el sur argentino hacia 1921.

XII Entrevista personal concedida por Carlos Echeverría, 18-03-2009.

XIII Silvia Schwarzböck, Los espantos. Estética y postdictadura (Buenos Aires: Cuarenta Ríos, 2016), 23. 